\title{
Management of Perforating External Cervical Root Resorption
}

\author{
Evaluation of Admissions and Incidence of Endodontic Treatment of Geriatric Patients in a \\ University Hospital
}

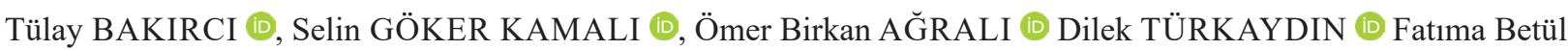 \\ BAŞTÜRK (D, Ayşe KARADAYI, (1) Hesna SAZAK ÖVEÇOĞLU (D)
}

\begin{abstract}
Introduction: External cervical resorption (ECR) is the loss of dental hard tissue as a result of odontoclastic action; it usually begins on the cervical region of the root surface of the teeth. The etiology and predisposing factors are not very clear. The aim of this case report is to show the management of maxillary right canine diagnosed with ECR.

Case Report: A 54-year old female patient was referred to our clinic with the history of dentin hypersensitivity in maxillary right anterior area. Radiographic examination revealed a radiolucent lesion located on the cervical third of maxillary right canine. The tooth was clinically asymptomatic. The patient did not report any traumatic history. CBCT scans revealed the extent of the resorption cavity and confirmed the diagnosis of the lesion.

Due to perforation of the resorption into the root canal space, the access cavity was opened and temporarily occluded with a gutta-percha point. Then the surgical repair of the resorptive defect was carried out without blocking the root canal with filling material. A mucoperiosteal flap was elevated to clean the granulamatous tissue. The lesion was apparent after complete degranulation of soft tissue. It was repaired with MTA-Angelus (Angelus, Londrina, PR, Brazil), a glass ionomer and a composite resin. The flap was replaced and sutured. Once the ECR cavity was restored, then endodontic treatment was completed in the same appointment. The root canal was obturated with gutta percha and root canal sealer by cold lateral condensation.
\end{abstract}

Tülay BAKIRCI (凶)

Department of Endodontics, Faculty of Dentistry, Marmara University, Istanbul, TURKEY

tulaybakirci@outlook.com

Selin GÖKER KAMALI, Dilek TÜRKAYDIN, Fatıma Betül BAŞTÜRK, Ayşe KARADAYI, Hesna SAZAK ÖVEÇOĞLU

Department of Endodontics, Faculty of Dentistry, Marmara University, Istanbul, TURKEY

Ömer Birkan AĞRALI

Department of Periodontology, Faculty of Dentistry, Marmara University, Istanbul, TURKEY

Submitted / Gönderilme: 25.12.2019

Accepted / Kabul: 27.12.2019
Conclusion: In the 9-month follow-up examination, the tooth including ECR defect was completely asymptomatic and functional.

Early detection is necessary for successful management and outcome of ECR. CBCT should be considered for the assessment and/or management of ECR.

Keywords: External Cervical Resorption, Cone-Beam Computed Tomography, Endodontic Treatment

\section{Öz}

Giriş: Eksternal servikal rezorpsiyon, diş sert dokularının odontoklastik aktivite sonucu kaybıdır ve genellikle kök yüzeyinin servikal bölgesinde başlar. Etiyolojisi ve predispozan faktörler tam olarak anlaşılamamıştır. Bu olgu bildiriminin amacı; eksternal servikal rezorpsiyonlu üst kanin dişine ait tedavi yaklaşımını sunmaktır.

Olgu Bildirimi: Elli dört yaşında kadın hasta sağ üst ön bölgede dentin hassasiyeti şikayetiyle kliniğimize başvurdu. Radyografik incelemede sağ üst kanin dişinde servikal bölgede radyolusent lezyon saptand. Diş klinik olarak asemptomatikti ve hastadan alınan anamnezde herhangi bir travma hikayesi olmadığ öğrenildi. Konik 1şınlı bilgisayarlı tomografi (CBCT) taramaları lezyon tanısını doğruladı ve lezyon kavitesinin sınırlarını ortaya çıkard1.

Rezorpsiyonun kök kanal boşluğuna açılması nedeniyle endodontik giriş kavitesi açıldı. Kök kanalı geçici olarak güta perka kon ile tıkaçlandıktan sonra rezorptif defektin tamirine başlandı. Granülamatöz dokuyu tamamen temizlemek için mukoperiostal flep kaldırıldı. Bu bölgedeki granülasyon dokusu temizlendikten sonra açığa çıkan rezorbsiyon kavitesi MTA Angelus (Angelus, Londrina, PR, Brazil), cam iyonomer siman ve kompozit rezin kullanılarak onarıldı. Flep kapatıldıktan sonra aynı seansta kök kanal tedavisi tamamland1. Kök kanal dolgusu; kök kanal patı ve güta perka kon kullanılarak soğuk lateral kondensasyon tekniği ile yap1ld.

Sonuç: Dişin 9 aylık takibi sonucunda asemptomatik ve fonksiyonel olduğu görüldü.

Eksternal servikal rezorbsiyonun başarılı tedavisi için erken teşhis edilmesi çok önemlidir.

Tedavi planlamasında CBCT mutlaka göz önünde bulundurulmalıdır.

Anahtar Kelimeler: Eksternal Servikal Rezorbsiyon, Konik Işınlı Bilgisayarlı Tomografi, Endodontik tedavi 


\section{Introduction}

External cervical resorption (ECR) is the loss of dental hard tissue as a result of odontoclastic action; it usually begins on the cervical region of the root surface of the teeth $[1,2]$.

External cervical resorption (ECR) is one of the least understood types of resorption. This form of external resorption was described by Heithersay [3, 4].

The radiographic appearance of ECR is variable and influenced by the size and nature of the lesion. The lesions may be radiolucent (resorptive phase), radiopaque (reparative phase) or present as a combination of both depending on the stage of the ECR lesion [5-7].

The etiology of ECR remains unclear. There may be etiological factors which have not yet been identified. Previous orthodontic treatment, traumatic injury, internal bleaching, surgery and bruxism are the releated factors with ECR [4].In recent years, new studies have shown that other factors can also be linked to the initiation of ECR. Such as; extraction of a neighboring tooth, malocclusion, playing wind instruments, periodontitis, autotransplantation, transmission of feline viruses to humans, herpes zoster, chemotherapy treatment, the use of bisphosphonates and hypoxia $[1,2,8-18]$.

The most commonly affected teeth are maxillary incisors, canines, first molars and mandibular first molars $[2,5,13]$

External cervical resorption (ECR) has different classification. The Heithersay classification of ECR is based on 2-dimensional imaging. The Patel classification is 3-dimensional, based on periapical radiographs and $\mathrm{CBCT}$ [7]

Treatment options for ECR depend on the size, nature of the lesion, whether the defect has perforated the root canal system and the restorability of the tooth $[1,19]$.Accessibility of the resorptive defect is also important. A mucoperiosteal flap may have to be elevated to clean the granulamatous tissue. Before considering surgery, CBCT imaging should be used to locate the lesion accurately and to determine the relationship between the lesion and alveolar bone [20] The treatment options are; external repair of the resorptive defect with or without endodontic treatment, internal repair and root canal treatment, intentional replantation, periodic review and extraction $[5,19]$.

This case report presents the management of perforating eksternal cervical resorption.

\section{Case Report}

A 54-year old female patient was referred to our clinic with the history of dentin hypersensitivity in maxillary right anterior area. Radiographic examination revealed a radiolucent lesion located on the cervical third of maxillary right canine. The tooth was clinically asymptomatic. The patient did not report any traumatic history. CBCT scans revealed the extent of the resorption cavity and confirmed the diagnosis of the lesion (Figure 1).

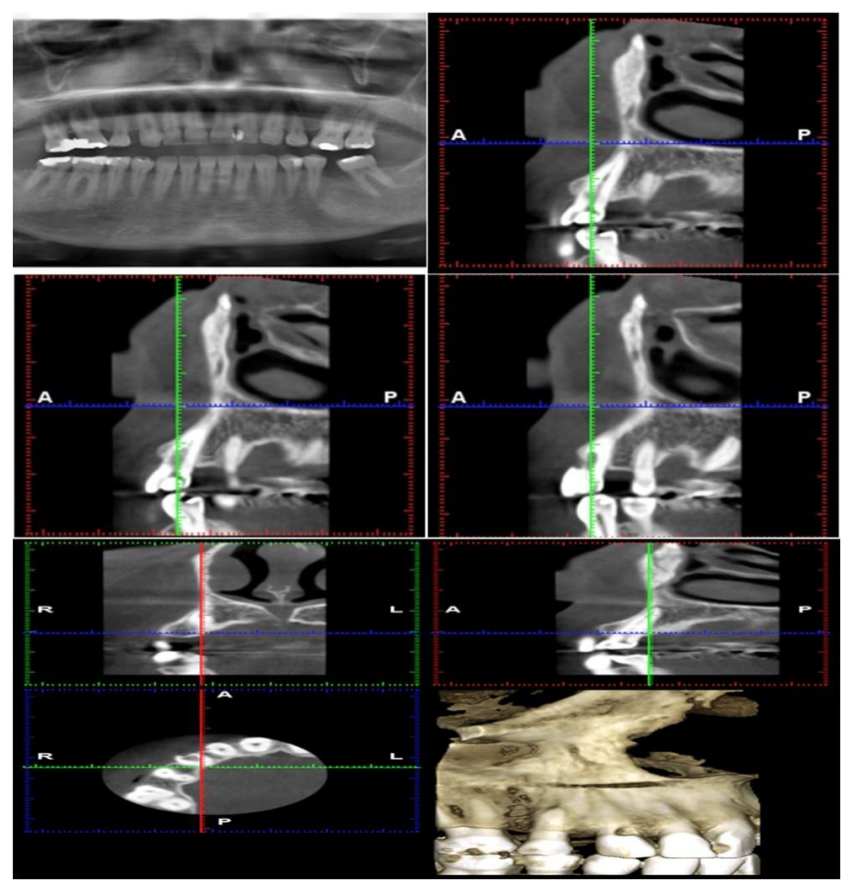

Figure 1. A panoramic radiograph and cone-beam computed tomographic images

Due to perforation of the resorption into the root canal space, the access cavity was opened and temporarily occluded with a gutta-percha point. Then the surgical repair of the resorptive defect was carried out without blocking the root canal with filling material. A mucoperiosteal flap was elevated to clean the granulamatous tissue. The lesion was apparent after complete degranulation of soft tissue. It was repaired with MTA-Angelus (Angelus, Londrina, PR,Brazil), a glass ionomer and a composite resin. The flap was replaced and sutured (Figure 2a-f). Once the ECR cavity was restored, then endodontic treatment was completed in the same appointment. The root canal was obturated with gutta percha and root canal sealer by cold lateral condensation (Figure 3). 


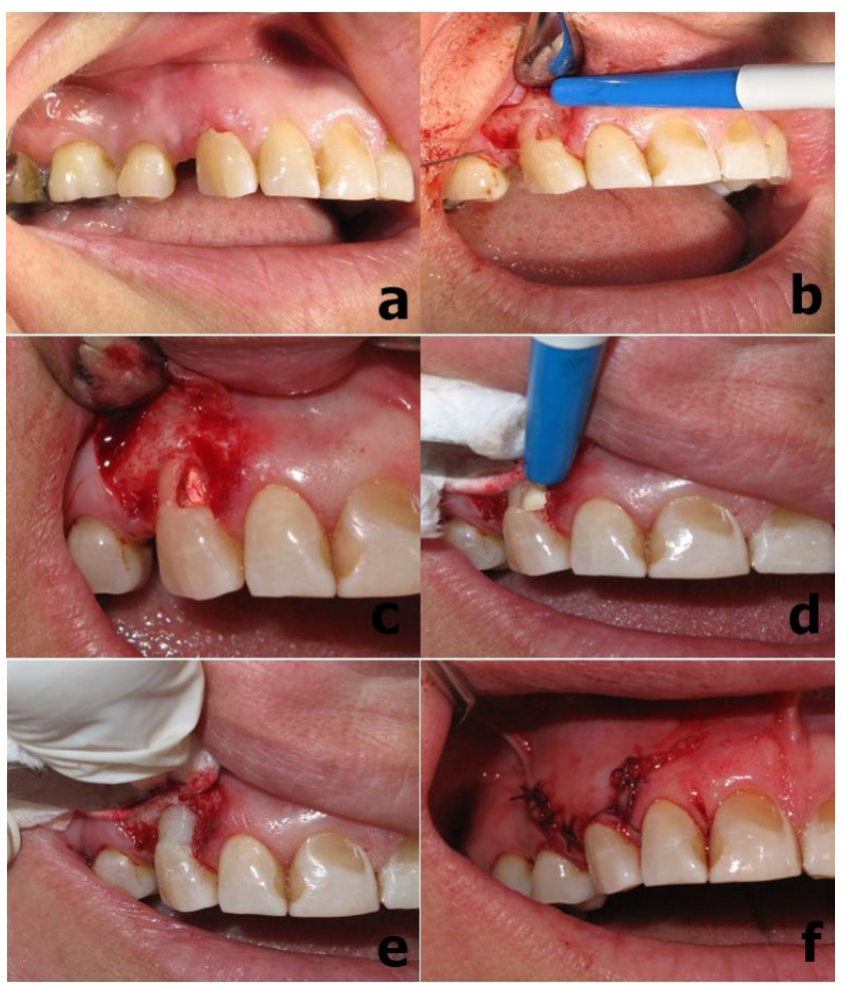

Figure 2. Surgical procedure

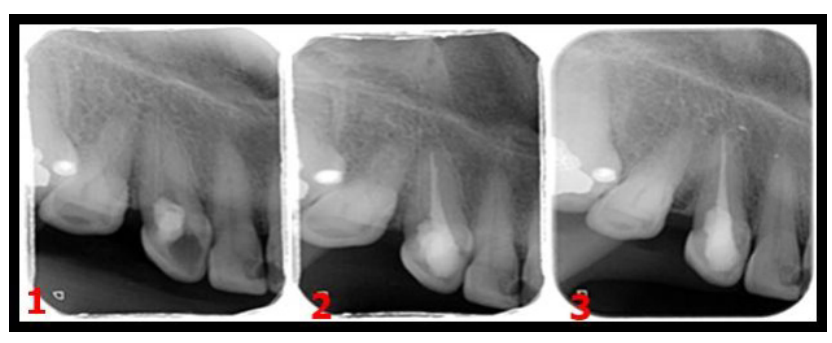

Figure 3. Periapical radiographs

\section{Discussion}

Treatment of ECR is a challenge to the clinician. Because ECR defects are often located subgingivally and interproximally. The condition is generally progressive[18]. Different treatment approaches for ECR have been described in the literature. Prognosis of treatment depends on the location,size and accessibility of the lesion.

This report presents a case with ECR. Endodontic treatment was required in this case because ECR perforated the root canal system. The root canal was accessed and occluded by inserting an appropriately sized gutta-percha point to maintain the patency of the canal during the subsequent excavation and restoration of the ECR defect. Once the ECR defect was restored, the mucoperiosteal flap repositioned and endodontic treatment was completed. This approach firstly prevents the unintentional blockage of the root canal and secondly provides a barrier against which the ECR restorative material may be condensed against $[19,21$, 22].

Radiography is essential to successful diagnosis of resorption. Cone beam computed tomography (CBCT) has enhanced radiographic diagnosis. The most important advantage of CBCT in endodontics is that it demonstrates anatomic features in 3D. CBCT can provide relevant information on the location and nature of root resorptive defects; although in two-dimensional imaging modalities the location and nature of the root resorptive defects may not be clear [23-28].

ECR has been accurately diagnosed and treated over the last decade; due to the histopathological techniques for its assessment and improved radiographic detection using CBCT. Early diagnosis and approriate treatment are the keys to manage external cervical resorption (ECR) effectively. Periapical radiography has significant limitations in accurately assessing the extent and nature of ECR and formulating an appropriate treatment plan. Therefore, CBCT should be considered for the assessment and/or management of ECR.

\section{Conclusion}

In the 9-month follow-up examination, the tooth including ECR defect was completely asymptomatic and functional.

Early detection is necessary for successful management and outcome of ECR. CBCT should be considered for the assessment and/or management of ECR.

\section{References}

1. Patel, S., S. Kanagasingam, and T.P. Ford, External cervical resorption: a review. Journal of endodontics, 2009. 35(5): p. 616-625.

2. Patel, S., et al., External cervical resorption part 1: histopathology, distribution and presentation. International endodontic journal, 2018. 51(11): p. 1205-1223.

3. Heithersay, G.S., Clinical, radiologic, and histopathologic features of invasive cervical resorption. Quintessence International, 1999. 30(1).

4. Heithersay, G.S., Invasive cervical resorption. Endodontic topics, 2004. 7(1): p. 73-92. 
5. by:, E.S.o.E.d., et al., European Society of Endodontology position statement: External Cervical Resorption. International Endodontic Journal, 2018. 51(12): p. 13231326.

6. Iqbal, M.K., Clinical and scanning electron microscopic features of invasive cervical resorption in a maxillary molar. Oral Surgery, Oral Medicine, Oral Pathology, Oral Radiology, and Endodontology, 2007. 103(6): p. e49-e54.

7. Patel, S., et al., External cervical resorption: a three dimensional classification. International endodontic journal, 2018. 51(2): p. 206-214.

8. Patel, S. and N. Saberi, External cervical resorption associated with the use of bisphosphonates: a case series. Journal of endodontics, 2015. 41(5): p. 742-748.

9. Solomon, C.S., M.O. Coffiner, and H.E. Chalfin, Herpes zoster revisited: implicated in root resorption. Journal of endodontics, 1986. 12(5): p. 210-213.

10. Von Arx, T., et al., Human and feline invasive cervical resorptions: the missing link? - Presentation of four cases. Journal of endodontics, 2009. 35(6): p. 904-913.

11. Vossoughi, R. and H.H. Takei, External cervical resorption associated with traumatic occlusion and pyogenic granuloma. Journal of the Canadian Dental Association, 2007. 73(7).

12. Mavridou, A.M., et al., Is Hypoxia Related to External Cervical Resorption? A Case Report. Journal of endodontics, 2019. 45(4): p. 459-470.

13. Mavridou, A.M., et al., Descriptive analysis of factors associated with external cervical resorption. Journal of endodontics, 2017. 43(10): p. 1602-1610.

14. Fuss, Z., I. Tsesis, and S. Lin, Root resorption-diagnosis, classification and treatment choices based on stimulation factors. Dental Traumatology, 2003. 19(4): p. 175-182.

15. Gunst, V., et al., Playing wind instruments as a potential aetiologic cofactor in external cervical resorption: two case reports. International endodontic journal, 2011. 44(3): p. 268-282.

16. Beertsen, W., et al., Generalized cervical root resorption associated with periodontal disease. Journal of clinical periodontology, 2001. 28(11): p. 1067-1073.
17. Patel, S. and N. Saberi, The ins and outs of root resorption. British dental journal, 2018. 224(9): p. 691.

18. Llavayol, M., et al., Multiple Cervical Root Resorption in a Young Adult Female Previously Treated with Chemotherapy: A Case Report. Journal of endodontics, 2019. 45(3): p. 349353.

19. Patel, S., et al., External cervical resorption: part 2management. International endodontic journal, 2018. 51(11): p. 1224-1238.

20. Schwartz, R.S., J.W. Robbins, and E. Rindler, Management of invasive cervical resorption: observations from three private practices and a report of three cases. Journal of endodontics, 2010. 36(10): p. 1721-1730.

21. Patel, K., F. Mannocci, and S. Patel, The assessment and management of external cervical resorption with periapical radiographs and cone-beam computed tomography: a clinical study. Journal of endodontics, 2016. 42(10): p. 14351440.

22. Hargreaves, K.M. and L.H. Berman, Cohen's pathways of the pulp expert consult. 2015: Elsevier Health Sciences.

23. Scarfe, W.C., et al., Use of cone beam computed tomography in endodontics. International journal of dentistry, 2009. 2009.

24. Vasconcelos, K.d.F., et al., Diagnosis of invasive cervical resorption by using cone beam computed tomography: report of two cases. Brazilian dental journal, 2012. 23(5): p. 602607.

25. Patel, S., et al., The detection and management of root resorption lesions using intraoral radiography and cone beam computed tomography-an in vivo investigation. International endodontic journal, 2009. 42(9): p. 831-838.

26. Patel, S. and A. Dawood, The use of cone beam computed tomography in the management of external cervical resorption lesions. International endodontic journal, 2007. 40(9): p. 730-737.

27. Patel, S., et al., The potential applications of cone beam computed tomography in the management of endodontic problems. International endodontic journal, 2007. 40(10): p. 818-830.

28. Patel, S., New dimensions in endodontic imaging: Part 2. Cone beam computed tomography. International endodontic journal, 2009. 42(6): p. 463-475. 